\title{
CONSTRUCTION OF RADIATION-REDUCED HYBRIDS AND THEIR USE IN MAPPING OF MICROCLONES FROM CHROMOSOME 10p11.2-q11.2
}

\author{
Shoichi Fujita, ${ }^{1,2}$ Eisei Shin, ${ }^{1,2}$ Tsutomu NaKamura, ${ }^{1}$ \\ Hiroki Kurahashi, ${ }^{1}$ Yasufumi Kanfda, ${ }^{3}$ Kiyoji TanaKa, ${ }^{3}$ \\ Takesada MoRI, ${ }^{2}$ Shin-ichiro TAKAI, ${ }^{1}$ and Isamu NisHISHO ${ }^{1, *}$ \\ ${ }^{1}$ Division of Clinical Genetics, Department of Medical Genetics, Biomedical Research Center and \\ ${ }^{2}$ Second Department of Surgery, Osaka University Medical School, \\ 2-2 Yamadaoka, Suita, Osaka 565, Japan \\ ${ }^{3}$ Institute for Molecular and Cellular Biology, Osaka University, \\ 1-3 Yamadaoka, Suita, Osaka 565, Japan
}

\begin{abstract}
Summary Radiation-reduced hybrids for mapping of DNA markers in the pericentromeric region of chromosome 10 were developed. A Chinese hamster/human somatic cell hybrid (762-8A) carrying chromosomes 10 and $\mathrm{Y}$ as the only human material were exposed to 40,000 rads of irradiation and then rescued by fusion with non-irradiated recipient Chinese hamster cells (GM459). Southern hybridization analyses revealed that 10 of 128 HAT-resistant clones contained human chromosomal fragments corresponding to at least one marker locus between FNRB (10p11.2 ) and $R B P 3$ (10q11.2). These hybrids were then used to map microdissection clones previously isolated and roughly mapped to this chromosomal region by fluorescence in situ hybridization (FISH). Two of the six microclones studied could be mapped to the proximity of the D10S102 locus. These radiation hybrids are useful for the construction of refined genetic maps of the pericentromeric region of chromosome 10 .
\end{abstract}

Key Words radiation-reduced hybrid, microdissection clone, gene mapping, multiple endocrine neoplasia type 2 (MEN 2)

\section{INTRODUCTION}

Somatic cell hybrids generated by means of irradiation and fusion techniques have been successfully used for high-resolution genetic mapping and as resources for isolating DNA fragments from defined chromosomal regions. In this tech-

Received July 9, 1993; Revised version received September 28, 1993; Accepted October 12, 1993.

*To whom correspondence should be addressed. 
nique, lethally irradiated cells are rescued by fusion with non-irradiated recipient cells, resulting in the generation of hybrid cells containing chromosomal fragments derived from the specific region of interest. The radiation hybrid mapping was first introduced by Goss and Harris (1975) and applied by Cox et al. (1990) to the construction of a high-resolution map of the proximal $20 \mathrm{Mb}$ of the long arm of human chromosome 21. Combined with meiotic mapping and pulsed-field gel electrophoresis (PFGE) analysis, this mapping procedure constitutes a powerful method for the construction of refined genetic maps of human genomes (Bishop and Crockford, 1992). In addition, the obtained hybrids containing chromosomal fragments from selected regions of human genomes can be used as a DNA source for the construction of a region specific genomic library.

Multiple endocrine neoplasia type 2A (MEN 2A) is a familial cancer syndrome, involving medullary thyroid carcinoma (MTC), adrenal gland pheochromocytoma, and parathyroid hyperplastic lesions, which is inherited as an autosomal dominant trait. Linkage studies have placed the gene responsible for MEN 2A at the pericentromeric region of chromosome 10 (Mathew et al., 1987; Simpson et al., 1987). Genes for two related disorders, multiple endocrine neoplasia type 2B (MEN 2B) and familial medullary thyroid carcinoma (MTC1), have also been mapped to the pericentromeric region of the chromosome (Norum et al., 1990; Lairmore et al., 1991). Extensive studies have been carried out to identify genetic alterations related to these hereditary syndromes. These studies include fine scale linkage and physical mapping (Bowden et al., 1989; Lichter et al., 1992; Mathew et al., 1987; Miller et al., 1992; Nakamura et al., 1989; Simpson et al., 1987; Wu et al., 1990; McDonald et al., 1992), isolation of YAC clones (Lairmore et al., 1992, 1993), and identification of several expressed genes (Brooks et al., 1992a; Rousseau et al., 1992).

Recently we isolated microclones from the pericentromeric region of chromosome 10 by microdissection of 10q11.1-q21.1 (Karakawa et al., 1993). Some of the microclones were expanded into cosmid-sized inserts and mapped to the pericentromeric region of the chromosome by fluorescence in situ bybridization (FISH). In order to map these microclones more finely and to obtain DNA resources for construction of a region-specific genomic library, we have constructed radiationreduced hybrids and successfully mapped two microclones to the proximity of the D10S102 locus.

\section{MATERIALS AND METHODS}

Cell lines. Two cell lines, 762-8A and GM459, were used. Cell line 762-8A, which was kindly donated by Dr. Carol Jones, contains chromosome 10 and $\mathrm{Y}$ as its only human component in a Chinese hamster genomic background (Fisher et al., 1987). GM459 is a near-diploid Chinese hamster cell line deficient in hypoxanthine-guanine phosphoribosyl-transferase (HPRT) activity obtained from the NIGMS Human Cell Repository (Camden, NJ). The 762-8A cells were kept in 
Ham's F-12 medium and GM459 cells in Dulbecco's modified Eagle's medium (DMEM), both supplemented with $10 \%$ fetal bovine serum, $100 \mathrm{U} / \mathrm{ml}$ penicillin, and $100 \mu \mathrm{g} / \mathrm{ml}$ streptomycin.

Production of radiation hybrids. $762-8 \mathrm{~A}$ cells $\left(10 \mathrm{ml}\right.$, approximately $2 \times 10^{7}$ cells) were exposed to 40,000 rads of irradiation with a Rigaku RF-350 X-ray unit $(180 \mathrm{keV}, 15 \mathrm{~mA})$ at a rate of $510 \mathrm{rads} / \mathrm{min}$. Following irradiation, $5 \mathrm{ml}$ of irradiated $762-8 \mathrm{~A}$ cells (approximately $10^{7}$ cells) was immediately added to $5 \mathrm{ml}$ of unirradiated GM459 cells (approximately $10^{7}$ cells), mixed, and centrifuged at $1,000 \mathrm{rpm}$ for $4 \mathrm{~min}$. These two kinds of cells were fused with the aid of polyethylene glycol or Hemagglutinating virus of Japan (HVJ). During cell fusion with polyethylene glycol, $0.5 \mathrm{ml}$ of $50 \%$ polyethylene glycol $1000(\mathrm{w} / \mathrm{v})$ was added to the cell pellet with gentle mixing. The cells were then incubated in a $37^{\circ} \mathrm{C}$ water bath for 60 min. During fusion with $\mathrm{HVJ}$, the cell pellet was suspended in 0.5 $\mathrm{ml}$ BSS (balanced salt solution; $140 \mathrm{~mm} \mathrm{NaCl}, 5.4 \mathrm{mM} \mathrm{KCl}, 10 \mathrm{~mm}$ Tris- $\mathrm{HCl}$, pH 7.6) containing $1 \mathrm{mM} \mathrm{CaCl}_{2}$. The cell suspension was mixed with $0.5 \mathrm{ml}$ of HVJ $(1,000 \mathrm{HAU} / 0.5 \mathrm{ml})$, kept at $4^{\circ} \mathrm{C}$ for $5 \mathrm{~min}$ and then incubated in a $37^{\circ} \mathrm{C}$ water bath for $30 \mathrm{~min}$ while being shaken. Both of the fusion mixtures were centrifuged and re-suspended in $20 \mathrm{ml}$ of DMEM containing $10 \%$ FBS. The cell suspension was then added to $100 \mathrm{~mm}$ plastic tissue culture dishes (20 in total), kept in DMEM for $24 \mathrm{~h}$. The supernatant was replaced with the HAT medium (DMEM plus $100 \mathrm{~mm}$ hypoxanthine, $12 \mathrm{~mm}$ thymidine, and $1 \mathrm{~mm}$ aminopterin), which was subsequently changed every three days. HAT resistant colonies appeared in two to three weeks and were cloned into $100 \mathrm{~mm}$ dishes. Under HAT selection, a single colony was picked, replated, and grown for isolation of DNA.

Southern blot analysis. High molecular weight DNAs $(10 \mu \mathrm{g})$ extracted from each of the hybrids, their parental cell lines and a human lymphoblastoid cell line with normal karyotype were completely digested with EcoRI, electrophoresed through $0.8 \%$ agarose gel, and then blotted onto nylon membranes (Pall BioSupport). The membranes were hybridized with DNA probes labeled with $\left[\alpha_{-}{ }^{32} \mathrm{P}\right]-$ $\mathrm{dCTP}$ by means of the random hexanucleotide-priming method (Feinberg and Vogelstein, 1984). Hybridization was performed overnight at $65^{\circ} \mathrm{C}$ in a solution containing $10 \% \mathrm{SDS}, 7 \%$ polyethylene glycol 8000 , and $200 \mu \mathrm{g} / \mathrm{ml}$ of human placental DNA.

Hybridizing probes. DNA markers used for characterization of the hybrid cells are listed in Table 1. For the D10S34 locus, a $4.0 \mathrm{~kb}$ EcoRI-subfragment of cTBQ14.34 was used as a hybridization probe. A cosmid clone, c710, corresponding to the D10S94 locus, was obtained by screening of a genomic cosmid library probed with the PCR product containing the MspI polymorphic site (Brooks et al., 1992b). The order of the 7 loci has been determined by meiotic and YAC physical mapping (Miller et al., 1992; Lairmore et al., 1993; Mole et al., 1993).

Mapping of microclones. Recently we obtained six microclones by microdissection of human chromosome 10q11.1-q21.1, which were mapped to the peri- 
Table 1. DNA probes used for characterization of radiation hybrids.

\begin{tabular}{|c|c|c|c|}
\hline Locus & Clone & Localization & Reference \\
\hline$F N R B$ & pGEM-32 & $10 p 11.2$ & Wu et al., 1989 \\
\hline D10S34 & cTBQ14.34a & $10 \mathrm{p} 13$-cen & Nakamura et al., 1988 \\
\hline $\mathrm{D} 10 \mathrm{Z1}$ & pA10RP8 & $10 c e n$ & Devilee et al., 1988 \\
\hline$R E T$ & $\mathrm{pN} 6 \mathrm{SB}$ & $10 q 11.2$ & Ishizaka et al., 1989 \\
\hline D10S94 & $c 710^{b}$ & 10cen-q11.2 & Goodfellow et al., $1990 \mathrm{~b}$ \\
\hline $\mathrm{D} 10 \mathrm{~S} 102$ & cMEN203W1T1 & $10 \mathrm{q} 11.2$ & Mathew et al., 1991 \\
\hline$R B P 3$ & pH.4IRBP & $10 \mathrm{q} 11.2$ & Liou et al., 1987 \\
\hline
\end{tabular}

a A $4.0 \mathrm{~kb}$ EcoRI subfragment of D10S34 was used. b A $3.0 \mathrm{~kb}$ EcoRI subfragment of D10S94 was used.

centromeric region of the chromosome by FISH (Karakawa et al., 1993). These six microclones were individually hybridized to the 10 radiation hybrids under the same stringent conditions as described above.

Pulsed-field gel electrophoresis (PFGE). Agarose blocks containing high molecular weight DNA were prepared according to the method described by Chu et al. (1986). DNAs in agarose blocks were completely digested with six rarecutting enzymes (BssHII, KspI, MluI, NotI, SalI, and SfiI). Pulsed-field gel electrophoresis was performed on a transverse alternating field electrophoresis (TAFE) system (Beckman, Gene Line II).

\section{RESULTS}

A total of 128 hybrids fused with PEG 1000 or HVJ were obtained. The DNAs from these hybrids were hybridized with a series consisting of the seven markers previously mapped to the pericentromeric region of chromosome 10 to test for the presence or absence of the marker loci within the pericentromeric region of chromosome 10. As a result, 10 of the 128 hybrids proved to contain at least one marker locus. A representative autoradiogram of Southern hybridization is shown in Fig. 1 and characteristics of the 10 hybrids are schematically shown in Fig. 2A. During hybridization with pH.4IRBP (RBP3) and pGEM-32 (FNRB), cross-hybridizing signals were observed in the hamster DNAs, which could, however, be easily distinguished from the human specific signals by the difference in size.

Six microclones were individually hybridized to the 10 radiation-reduced hybrids. As shown in Fig. 2B, the hybridization patterns of $\mathrm{m} 135$ and m149-2 are identical to that of D10S102 locus, suggesting that these two microclones are located near the D10S102 locus. Moreover, m135 and m149-2 showed identical restriction patterns to those of cMEN203W1T1 in PFGE analysis (data not shown). 


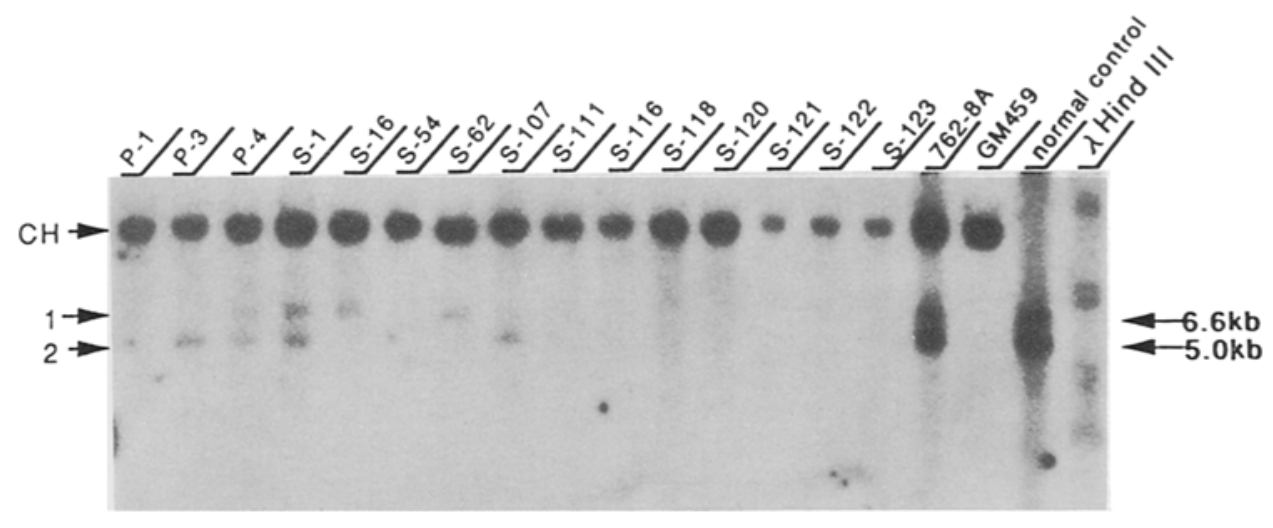

Fig. 1. Autoradiogram of Southern blot analysis of radiation hybrids. The DNA (10 $\mu \mathrm{g})$ of each hybrid cell was digested with EcoRI. Arrows 1 and 2 on the left indicate signals corresponding to the $R B P 3$ and $R E T$ loci, respectively. Arrow $\mathrm{CH}$ indicates cross-hybridizing hamster bands detected by the pH.4IRBP probe (RBP3). Three hybrid cells (P1-P4) are hybrids fused with polyethylene glycol and the remaining 12 hybrids (S1-S123) with the Sendai virus (Hemagglutinating virus of Japan). The sizes of the EcoRI bands are indicated on the right.

\section{DISCUSSION}

Irradiation-reduced hybrids for gene mapping were first developed by Goss and Harris (1975) using selection for the HPRT gene on the distal part of Xq. This procedure has been employed with modifications to produce cell lines useful for mapping genes on various human chromosomes such as chromosome 3 (Siden et al., 1992; Tamari et al., 1992), 4 (Cox et al., 1989; Doucette et al., 1991; Altherr et al., 1992), 5 (Warrington et al., 1991), 6 (Ragoussis et al., 1991; Zoghbi et al., 1991), 9 (Jackson et al., 1992), 10 (Goodfellow et al., 1990a; Rothschild et al., 1992), 11 (Glaser et al., 1990; Richard et al., 1991), 16 (Ceccherini et al., 1992), 21 (Graw et al., 1988; Burmeister et al., 1991; Boehnke, 1992), 22 (Frazer et al., 1992), and X (Benham et al., 1989; Benham and Rowe, 1992). Linkage analyses have been performed so far mainly for the mapping of DNA markers flanking the loci of specific hereditary diseases (Bowden et al., 1989; Lichter et al., 1992; Mathew et al., 1987; Miller et al., 1992; Nakamura et al., 1989; Simpson et al., 1987; Wu et al., 1990). When localization of the gene responsible for a certain hereditary disease is narrowed down to within a small region, fine mapping of flanking markers is required. In such instances, mapping by linkage analysis requires much time and effort to analyze a large number of meiosis in reference families. Moreover, ordering the flanking markers cannot be achieved when the recombination fraction $(\theta)$ is zero. Even in such instances, however, the resolution of closely linked markers could be enhanced by using radiation hybrids constructed with a high dose of irradiation. Another advantage of radiation hybrid mapping is that newly isolated 

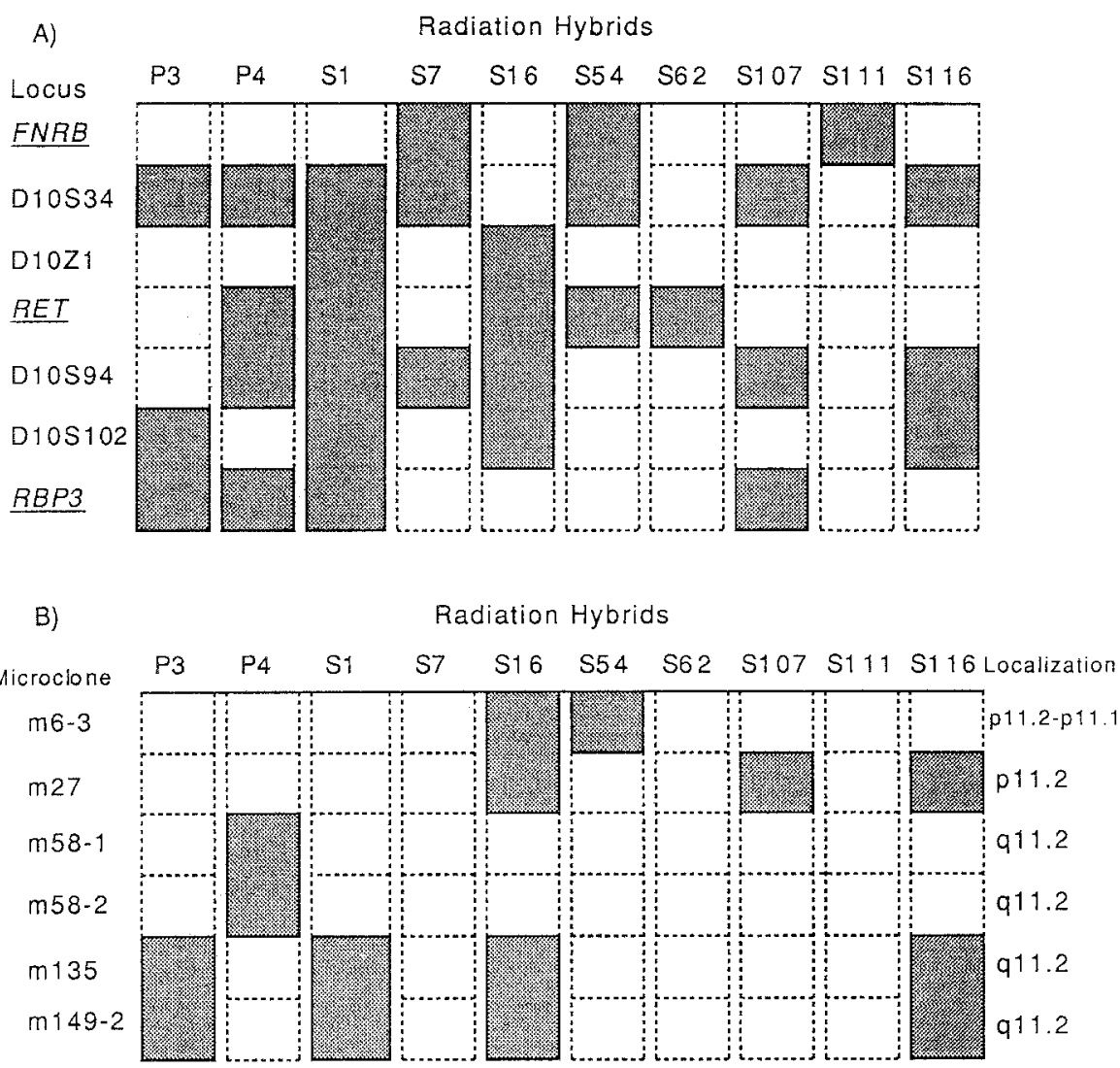

Fig. 2. Schematic representation of Southern blot analysis of radiation hybrids. Probes corresponding to the seven loci that had been previously localized in the pericentromeric region of chromosome 10 were used for characterization of the hybrids (A). Microclones mapped by FISH to the chromosomal region were used as probes (B). Presence (1) or absence (-...) of the corresponding signals is also shown.

genes or DNA fragments can be placed on the radiation hybrid panel without the need to develop polymorphisms.

For the high-resolution mapping of the pericentromeric region of chromosome 10 , we adopted a relatively high dose of irradiation $(40,000$ rads). As a result, we obtained 10 radiation hybrids which contain chromosomal fragments corresponding to at least one marker locus within the chromosomal region. These radiation hybrids were then used for mapping of microclones of which the corresponding cosmids had been roughly localized by FISH to the chromosomal region. As a rule, microclones obtained by microdissection cannot be easily mapped by linkage analysis or FISH, for which corresponding larger genomic fragments are often required. However, once radiation hybrid mapping panels have been con- 
structed, these microclones can be mapped more easily and rapidly. Two of the six microclones could be mapped near the D10S102 locus, but the remaining four microclones could not be localized with our mapping panel. One of the reasons may be that these microclones are located outside the chromosomal region between $F N R B$ and RBP3. Alternatively, a certain proportion of the pericentromeric region of the chromosome might not be included in these 10 radiation hybrids.

In addition to their usefulness for high-resolution mapping, radiation hybrids are valuable for isolation of DNA fragments from specific chromosomal regions of interest. One of the hybrids obtained in this study, S16, which contains chromosomal fragment from between the D10Z1 and D10S102 loci, could be used to isolate DNA fragments from the proximal portion of the long arm of chromosome 10 , in which gene(s) responsible for MEN 2A, MEN 2B, and MTC1 are thought to reside. Thus, the 10 radiation hybrids constructed by us and the two microclones regionally assigned to the proximity of the D10S201 will be useful for the construction of continuous physical maps of the pericentromeric region of chromosome 10.

Acknowledgments We would like to thank the following doctors for providing DNA probes: E. Ruoslahti for pGEM-32; Y. Nakamura for cTBQ14.34 and cMEN203W1T1; H. Willard for pA10RP8; Y. Ishizaka for pN6SB and C. Bridges for pH.41 RBP. In addition we thank Dr. Carol Jones for providing the hybrid cell line 762-8A. We are gratefu! to Miss Rikako Kohama for her technical assistance and Miss Shuko Nakano for assistance with the preparation of the manuscript.

This work was supported by a Grant-in-Aid for Cancer Research from the Ministry of Education, Science and Culture of Japan.

\section{REFERENCES}

Altherr MR, Plummer S, Bates G, MacDonald M, Taylor S, Lehrach H, Frischauf AM, Gusella JF, Boehnke M, Wasmuth JJ (1992): Radiation hybrid map spanning the Huntington disease gene region of chromosome 4. Genomics 13: 1040-1046

Benham F, Hart K, Crolla J, Bobrow M, Francavilla M, Goodfellow PN (1989): A method for generating hybrids containing nonselected fragments of human chromosomes. Genomics 4: $509-517$

Benham F, Rowe P (1992): Use of Alu-PCR to characterize hybrids containing multiple fragments and to generate new Xp21.3-p22.2 markers. Genomics 12: 368-376

Bishop DT, Crockford GP (1992): Comparisons of radiation hybrid mapping and linkage mapping. Cytogenet Cell Genet 59: 93-95

Boehnke M (1992): Genetic Analysis Workshop 7: radiation hybrid and somatic cell hybrid mapping of chromosome 21. Cytogenet Cell Genet 59: 74-76

Bowden DW, Gravius TC, Green P, Falls K, Wurster HD, Noll W, Muller KH, Donis KH (1989): A genetic linkage map of 32 loci on human chromosome 10 . Genomics 5: 718-726

Brooks WA, Smailus DE, Goodfellow PJ (1992a): A cluster of CpG islands at D10S94, near the locus responsible for multiple endocrine neoplasia type 2A (MEN2A). Genomics 13: 339-343

Brooks WA, Smailus D, Gilchrist D, Goodfellow PJ (1992b): Additional RFLPs at D10S94 and the development of PCR-based variant detection systems: implications for disease genotype prediction in MEN 2A, MEN 2B, and MTC1 families. Genomics 13: 233-234

Burmeister M, Kim S, Price ER, Lange TD, Tantravahi U, Myers RM, Cox DR (1991): A map of

Vol. 38, No. 4, 1993 
the distal region of the long arm of human chromosome 21 constructed by radiation hybrid mapping and pulsed-field gel electrophoresis. Genomics 9: 19-30

Ceccherini I, Romeo G, Lawrence S, Breuning MH, Harris PC, Himmelbauer H, Frischauf AM, Sutherland GR, Germino GG, Reeders ST, Morton NE (1992): Construction of a map of chromosome 16 by using radiation hybrids. Proc Natl Acad Sci USA 89: 104-108

Chu G, Vollrath D, Davis RW (1986): Separation of large DNA molecules by contour-clamped homogeneous electric fields. Science 234: 1582-1585

Cox DR, Pritchard CA, Uglum E, Cashier D, Kobori J, Myers RM (1989): Segregation of the Huntington disease region of human chromosome 4 in a somatic cell hybrid. Genomics 4: 397407

Cox DR, Burmeister M, Price ER, Kim S, Myers RM (1990): Radiation hybrid mapping: a somatic cell genetic method for constructing high-resolution maps of mammalian chromosomes. Science $250: 245-250$

Devilee P, Kievits T, Waye JS, Pearson PL, Willard HF (1988): Chromosome-specific alpha satellite DNA: Isolation and mapping of a polymorphic alphoid repeat from human chromosome 10. Genomics $3: 1-7$

Doucette SL, Riba L, Handelin B, Difilippantonio M, Ward DC, Wasmuth JJ, Gusella JF, Housman DE (1991): Generation and characterization of irradiation hybrids of human chromosome 4. Somat Cell Mol Genet 17: 471-480

Feinberg AP, Vogelstein B (1984): A technique for radiolabeling DNA restriction endonuclease fragments to high specific activity. Anal Biochem 137: 266-267

Fisher JH, Kao FT, Jones C, White RT, Benson BJ, Mason RJ (1987): The coding sequence for the 32,000-dalton pulmonary surfactant-associated protein $\mathrm{A}$ is located on chromosome 10 and identifies two separate restriction-fragment-length polymorphisms. Am J Hum Genet 40: $503-511$

Frazer KA, Boehnke M, Budarf ML, Wolff RK, Emanuel BS, Myers RM, Cox DR (1992): A radiation hybrid map of the region on human chromosome 22 containing the neurofibromatosis type 2 locus. Genomics 14: $574-584$

Glaser T, Rose E, Morse H, Housman D, Jones C (1990): A panel of irradiation-reduced hybrids selectively retaining human chromosome $11 \mathrm{p} 13$ : their structure and use of purify the WAGR gene complex. Genomics 6: 48-64

Goodfellow PJ, Myers S, Anderson LL, Brooks WA, Simpson NE (1990a): A new DNA marker (D10S94) very tightly linked to the multiple endocrine neoplasia type 2A (MEN2A) locus. Am J Hum Genet 47: 952-956

Goodfellow PJ, Povey S, Nevanlinna HA, Goodfellow PN (1990b): Generation of a panel of somatic cell hybrids containing unselected fragments of human chromosome 10 by X-ray irradiation and cell fusion: application to isolating the MEN2A region in hybrid cells. Somat Cell Mol Genet 16: 163-171

Goss SJ, Harris H (1975): New method for mapping genes in human chromosomes. Nature 255: $680-684$

Graw S, Davidson J, Gusella J, Watkins P, Tanzi R, Neve R, Patterson D (1988): Irradiationreduced human chromosome 21 hybrids. Somat Cell Mol Genet 14: 233-242

Ishizaka $Y$, Itoh F, Tahira T, Ikeda I, Sugimura T, Tucker J, Fertitta A, Carrano AV, Nagao M (1989): Human ret proto-oncogene mapped to chromosome 10q11.2. Oncogene 4: 1519-1521

Jackson CL, Britt DE, Graw SL, Potts A, Santoro K, Buckler AJ, Housman DE, Mark HF (1992): Construction and characterization of radiation hybrids for chromosome 9 , and their use in mapping cosmid probes on the chromosome. Somat Cell Mol Genet 18:285-301

Karakawa K, Takami K, Nakamura T, Carol J, Fujita S, Ohta T, Jinno Y, Niikawa N, Inazawa J, Ariyama T, Mori T, Takai S, Nishisho I (1993): Isolation of region-specific cosmids by hybridization with microdissection clones from human chromosome 10q11.1-q21.1. Genomics 17: $449-455$ 
Lairmore TC, Howe JR, Korte JA, Dilley WG, Aine L, Aine E, Wells SJ, Donis KH (1991): Familial medullary thyroid carcinoma and multiple endocrine neoplasia type $2 \mathrm{~B}$ map to the same region of chromosome 10 as multiple endocrine neoplasia type 2A. Genomics 9: 181-192

Lairmore TC, Howe JR, Dou S, Veile R, Korte SJ, Wells SJ, Donis KH (1992): Isolation of YAC clones from the pericentromeric region of chromosome 10 and development of new genetic markers linked to the multiple endocrine neoplasia type $2 \mathrm{~A}$ gene. Henry Ford Hosp Med J 40: $210-214$

Lairmore TC, Dou S, Howe JR, Chi D, Carlson K, Veile R, Mishima SK, Wells SA, Donis-Keller $H$ (1993): A 1.5-megabase yeast artificial chromosome contig from human chromosome 10q11.2 connecting three genetic loci $(R E T, D 10 S 94$, and D1OS102) closely linked to the MEN $2 A$ locus. Proc Natl Acad Sci USA 90: 492-496

Lichter JB, Wu J, Miller D, Goodfellow PJ, Kidd KK (1992): A high-resolution meiotic mapping panel for the pericentromeric region of chromosome 10. Genomics 13: 607-612

Liou GI, Wang C, Fong SL, Battacharya S, Bridges CDB (1987): BglII RFLP recognized by a human IRBP cDNA localized to chromosome 10. Nucleic Acids Res 15: 3196

Mathew CG, Chin KS, Easton DF, Thorpe K, Carter C, Liou GI, Fong SL, Bridges CD, Haak H, Kruseman AC, Schifter S, Hansen HH, Telenius H, Telenius-Berg M, Ponder BAJ (1987): A linked genetic marker for multiple endocrine neoplasia type $2 \mathrm{~A}$ on chromosome 10 . Nature 328: $527-528$

Mathew CG, Easton DF, Nakamura Y, Ponder BA (1991): Presymptomatic screening for multiple endocrine neoplasia type 2A with linked DNA markers. The MEN 2A International Collaborative Group. Lancet 337: 7-11

McDonald H, Smailus D, Jenkins H, Adams K, Simpson NE, Goodfellow PJ (1992): Identification and characterization of a gene at D10S94 in the MEN 2A region. Genomics 13: 344-348

Miller DL, Dill FJ, Lichter JB, Kidd KK, Goodfellow PJ (1992): Isolation and high-resolution mapping of new DNA markers from the pericentromeric region of chromosome 10. Genomics 13: $601-606$

Mole SE, Mulligan LM, Healey CS, Ponder BA, Tunnacliffe A (1993): Localisation of the gene for multiple endocrine neoplasia type $2 \mathrm{~A}$ to a $480 \mathrm{~kb}$ region in chromosome band 10q11.2. Hum Mol Genet 2: 247-252

Nakamura Y, Lathrop M, Bragg T, Leppert M, O'Connell P, Jones C, Lalouel JM, White R (1988): An extended genetic linkage map of markers for human chromosome 10. Genomics 3: 389392

Nakamura Y, Mathew CG, Sobol H, Easton DF, Telenius H, Bragg T, Chin K, Clark J, Jones C, Lenoir GM, White R, Ponder BAJ (1989): Linked markers flanking the gene for multiple endocrine neoplasia type 2A. Genomics 5: 199-203

Norum RA, Lafreniere RG, O'Neal LW, Nikolai TF, Delaney JP, Sisson JC, Sobol H, Lenoir GM, Ponder BA, Willard HF, Jackson CE (1990): Linkage of the multiple endocrine neoplasia type 2B gene (MEN 2B) to chromosome 10 markers linked to MEN 2A. Genomics 8: 313-317

Ragoussis J, Jones TA, Sheer D, Shrimpton AE, Goodfellow PN, Trowsdale J, Ziegler A (1991): Isolation of probes specific to human chromosomal region $6 \mathrm{p} 21$ from immunoselected irradiation-fusion gene transfer hybrids. Genomics 10: 598-607

Richard C3, Withers DA, Meeker TC, Maurer S, Evans GA, Myers RM, Cox DR (1991): A radiation hybrid map of the proximal long arm of human chromosome 11 containing the multiple endocrine neoplasia type 1 (MEN 1) and bcl-1 disease loci. Am J Hum Genet 49: 1189-1196

Rothschild CB, Noll WW, Gravius TC, Schuster MK, Nutile MN, Jones C, Bowden DW (1992): Characterization of radiation/fusion hybrids containing parts of human chromosome 10 and their use in mapping chromosome 10-specific probes. Genomics 13: 25-34

Rousseau MM, Tunnacliffe A, Berger R, Ponder BA, Thiesen HJ (1992): A cluster of expressed zinc finger protein genes in the pericentromeric region of human chromosome 10. Genomics 13: $845-848$

Vol. 38, No. 4, 1993 
Siden TS, Kumlien J, Schwartz CE, Rohme D (1992): Radiation fusion hybrids for human chromosomes 3 and $X$ generated at various irradiation doses. Somat Cell Mol Genet 18: 33-44

Simpson NE, Kidd KK, Goodfellow PJ, McDermid H, Myers S, Kidd JR, Jackson CE, Duncan AM, Farrer LA, Brasch K, Castiglione C, Ganel M, Gertner J, Greenberg CR, Gusella JF, Holden JJA, White BN (1987): Assignment of multiple endocrine neoplasia type 2A to chromosome 10 by linkage. Nature 328: $528-530$

Tamari M, Hamaguchi M, Shimizu M, Oshimura M, Takayama H, Kohno T, Yamaguchi N, Sugimura T, Terada M, Yokota $\mathfrak{J}$ (1992): Ordering of human chromosome 3 p markers by radiation hybrid mapping. Genomics 13: 705-712

Warrington JA, Hall LV, Hinton LM, Miller JN, Wasmuth JJ, Lovett M (1991): Radiation hybrid map of 13 loci on the long arm of chromosome 5. Genomics 11: 701-708

Wu JS, Giuffra LA, Goodfellow PJ, Myers S, Carson NL, Anderson L, Hoyle LS, Simpson NE, Kidd KK (1989): The beta subunit locus of the human fibronectin receptor: DNA restriction fragment length polymorphism and linkage mapping studies. Hum Genet 83: 383-390

Wu JS, Myers S, Carson N, Kidd JR, Anderson L, Castiglione CM, Hoyle LS, Lichter JB, Sukhatme VP, Simpson NE, Kidd KK (1990): A refined linkage map for DNA markers around the pericentromeric region of chromosome 10. Genomics 8: 461-468

Zoghbi HY, McCall AE, LeBorgne DF (1991): Sixty-five radiation hybrids for the short arm of human chromosome 6: their value as a mapping panel and as a source for rapid isolation of new probes using repeat element-mediated PCR. Genomics 9: 713-720 